\title{
Barroco y Modernidad: hacia una ética materialista de la representación (de uno mismo)
}

\section{Baroque and Modernity: towards a Materialist Ethics of (Self)Representation}

\author{
Óscar Cornago \\ Consejo Superior de Investigaciones Científicas de Madrid, España \\ oscarcornago@yahoo.com
}

Resumen - Cualquier forma de representación implica una actitud, y por tanto una ética, hacia ese ejercicio de representación. Desde tal perspectiva, el presente artículo explora las relaciones entre la construcción de la Modernidad cultural y un imaginario del barroco que, curiosamente, no ha dejado de acompañarla. A partir del pensamiento de algunos exponentes de la "filosofía materialista», como Nietzsche, Benjamin, Adorno, Deleuze, Lyotard o Sloterdijk, y en referencia a distintos nombres del campo de la literatura (Mallarmé, Elias Canetti, Juan Goytisolo, Miguel Romero Esteo) y el cine (Jean-Luc Godard, Greenaway), se discuten distintas maneras de entender y actuar frente al hecho de la representación.

Palabras clave: Modernidad, Barroco, teoría de la representación, posestructuralismo.

Abstract • Any form of representation implies an attitude, and therefore an ethic, to the exercise of representation. From this perspective, this article explores the relationship between the construction of cultural modernity and baroque imagination. Considering the thoughts of a few names of the "materialist philosophy», such as Nietzsche, Benjamin, Adorno, Lyotard or Sloterdijk, literature (Juan Goytisolo, Miguel Romero Esteo, Mallarmé, Elias Canetti) and film (Jean-Luc Godard, Greenaway), this paper will discuss different ways of understanding and responding to the fact of representation in Modernity.

Key words: Modernity, Baroque, Theory of representation, Post-structuralism. 
Es preciso querer incluso la ilusión: en esto consiste lo trágico.

Friedrich Nietzsche, El libro del filósofo

En la parte primera, "Reino 1: Infierno", de Nuestra música, Godard hace un montaje con escenas de guerra que dura unos siete u ocho minutos: masacres, ejecuciones, poblaciones huyendo, ciudades destruidas y cuerpos sometidos, puestas en escena del poder y la muerte en épocas distintas, imágenes que se suceden con rapidez. Unas parecen reales - diríamos que son de archivo o documentales-, otras son citas de la desbordante enciclopedia cinematográfica del siglo XX; en todo caso, todas han sido filmadas, todas son imágenes. Su condición última de imágenes se acentúa por la calidad granulosa, táctil, y los contornos difusos de muchas de ellas. Los escenarios de la Modernidad nos hablan de destrucción y de imágenes, por ello quizá inevitablemente también de construcciones (mediáticas); ahí radica su falta de pudor, pero también su posible ética, en mostrarse como construcción, como representación. Se destruye algo y luego se trata de (re)construir: un lenguaje, una obra, un país, una persona o un paisaje. En ello consiste el negocio económico, editorial, crítico, personal, semiótico o ecológico, en un continuo acto de construcción y destrucción, sobre el que luego se articulan las historias, historias de guerras y violaciones, imágenes convertidas en íconos, relatos míticos de la Modernidad, siempre parecidos y siempre distintos, relatos legitimadores con los que demostrar quién tenía razón, la legitimación de la violencia, del asesinato.

"Si se mata a un hombre por defender una idea, no se defiende una idea, se mata a un hombre», se oye decir en la película de Godard. La melodía de Nuestra música, también de El sitio de los sitios, cuyo autor, Juan Goytisolo, aparece como personaje prestando voz (palabra) en la segunda parte "Reino 2: Purgatorio", que tiene lugar en Sarajevo, en torno a los Encuentros Europeos del Libro, nos habla de destrucción, pero también de resistencia, de la liberación a través de un acto de afirmación, afirmación de la palabra, de las imágenes o los cuerpos, incluso a través del suicidio, de la autoinmolación, como el de la joven protagonista (Sarah Adler), que se hace asesinar por soldados israelíes aparentando llevar una caja bomba atada a la cintura, que en realidad sólo contenía libros. Pulsión de muerte, dirá Lyotard (Dispositivos pulsionales, 299), «no porque busque la muerte, sino porque es afirmación parcial, singular, y subversión de totalidades aparentes (el Ego, la Sociedad) en el instante de la afirmación», para añadir inmediatamente: «Toda elevada emoción es efecto de la muerte, disolución de lo acabado, de lo histórico». De eso también tratan las representaciones barrocas de la Modernidad, de destrucción, muerte y apariencias — sobre todo mediáticas-, del silencio y la creación (poética), de la más elevada emoción como acto de liberación, de afirmación (crítica) del presente.

\section{BARROCO Y MODERNIDAD: DISQUISICIONES METODOLÓGICAS}

El objetivo del presente ensayo es delimitar la figura formada por el discurso de lo barroco sobre el mapa de la Modernidad, indagar en la función que el pensamiento del barroco ha tenido, no ya para el esclarecimiento o exégesis de un período histórico pretérito, 
sino dentro del propio presente desde el que se enuncia, es decir, de un amplio marco temporal que arranca en la segunda mitad del siglo XIX, cuando el debate adquiere una formulación más compleja - a pesar de que sus antecedentes se pueden seguir desde los umbrales de la Modernidad, con la oposición del llamado «espíritu ilustrado»-, hasta llegar a nuestros días, en los que no se ha dejado de discutir esa difusa idea de lo barroco, tan pronto empleada para caracterizar un período de la cultura occidental como para teñir toda la contemporaneidad mediática y espectacular o incluso la propia condición humana en un sentido ontológico.

En el Libro de los pasajes, Walter Benjamin, guía por excelencia para adentrarse en ese barroco mapa de la Modernidad, afirma que para el historiador materialista todo pasado es siempre la antehistoria de su presente; por remoto que resulte el objeto de estudio, éste se mira inevitablemente con los ojos del presente. Por ello, todo tiempo pretérito, en la medida en que se transmite a través de un discurso constantemente reformulado desde un aquí y un ahora, está cargado de presente. Si atendemos al barroco histórico y la conceptualización desde la que se ha acuñado el término, ello se hace especialmente evidente. Desde sus orígenes el término barroco ha dado lugar a un espacio de controversias que no ha dejado de transformarse hasta la actualidad. De modo particularmente claro, la idea de barroco ha permitido pensar al mismo tiempo un pasado histórico y el presente desde el que se mira. Así, ese tiempo pretérito, pensemos en el siglo XVII, se ha erigido de forma casi natural en antesala de nuestro presente, haciendo borrosos los límites que marcan el comienzo y el fin de esa época (barroca) que la Modernidad parece irradiar desde su centro más controvertido hasta sus márgenes más difusos. De ahí que Benjamin continúe diciendo que para el historiador materialista no hay apariencia de repetición, es decir, no hay sensación de que lo mismo está volviendo a suceder, como haría suponer aquel eon recurrente al que se refería Eugenio d'Ors, pues «los momentos del curso de la historia que más le conciernen pasan a ser, en virtud de su índice ‘antehistórico`, momentos del presente mismo» (N 9 a, 8).

Una reflexión sobre el barroco, ya lo pensemos como idea cultural, discurso estético o período histórico, hace visible la condición histórica del propio concepto; deja ver las huellas de las contingencias pragmáticas desde las que se ha reformulado y se sigue reformulando hasta hoy mismo. Trasladando ese comportamiento a otros ámbitos, la reflexión sobre el barroco denuncia a su vez la condición igualmente histórica de cualquier otro discurso crítico o historiográfico. Los conceptos se acuñan en un momento en respuesta a unas necesidades de presente; a partir de ahí no dejan de vivir en la historia, modificándose al ritmo que se transforman los tiempos y las preguntas que éstos plantean, las inquietudes que mueven la historia y marcan los cauces del pensamiento. Bajo un mismo término se ocultan contenidos siempre distintos; no es igual el modo de considerar hoy el barroco que lo que se entendía hace cien años, cuando Heinrich Wöllflin y los teóricos de la Pura Visibilidad lo distinguieron como una idea clave para articular un relato universalista de la evolución de las formas artísticas, o como se pensó cuando surgió en el horizonte cultural de las vanguardias en los años veinte. Necesariamente, el espacio cultural afectado por ese término se ha ido modificando al tiempo que su propio contenido no ha dejado de ser otro.

Entre los muchos empleos que ha conocido se encuentra el de delimitar un período de la cultura de Occidente en torno al seiscientos. Pero ningún concepto responde únicamente a la necesidad de acuñar un discurso historiográfico o una idea estética; siguiendo 
al historiador materialista, diríamos que antes que nada responde a una contingencia política, a la pragmática académica y cultural desde la que se formula, una pragmática que - aunque académica, o sobre todo por académica- nos habla en primer lugar de su presente. Un concepto delimita también un campo de poder y representación cultural, social y política, un espacio gobernado desde determinados intereses; puede ser un negocio, académico o editorial, e incluso un engaño, un trampantojo, reflejo quizá de su propia condición barroca cuando se hace visible como puesta en escena de su propio discurso.

En la historia de España ese período ha llegado a delimitar una de las épocas de mayor esplendor artístico, convertida por algunos en paradigma y esencia del ser español, reformulado luego en un paradójico giro identitario para Latinoamérica. Pero de todo ello no hace mucho tiempo, antes fue muy distinta la consideración de esa tendencia artística. Es con las vanguardias históricas y la intensa recuperación académica a partir de los años sesenta que el concepto de barroco se encuentra fuertemente capitalizado en la historia cultural hispánica, lo que explica que más de uno, autoerigido en ilustre heredero de tan rancia tradición, prefiera guardarlo celosamente para que el término signifique eso y no ninguna otra cosa, aquello para lo cual se encuentra justificación en un fundamentado relato historiográfico. Quizá por ello no resulta fácil hablar dentro del hispanismo, menos si es literario, de la idea del barroco que cubre el siglo de Cervantes, Quevedo y Calderón, para trasladarla como instrumento hermenéutico a épocas más recientes.

Empecemos, pues, por el comienzo: ¿qué nos legitima, entonces, desde un punto de vista metodológico, a hablar del barroco en los siglos XIX y XX? La respuesta más inmediata, de orden epistemológico, sería el hecho de que dicho concepto historiográfico se acuña en ese período; es en la década de los sesenta del siglo XIX cuando Jacob Burckhardt constata significativos cambios, aunque todavía incipientes, en los gustos estéticos, y unos años más tarde un alumno aventajado, Friedrich Nietzsche, le dedica un parágrafo de su Humano, demasiado humano, proyectando la idea de lo barroco hacia esferas estéticas y filosóficas más amplias. Ello no sería sino la antesala de una polémica que no ha dejado de producir ensayos, estudios y disputas sobre cómo entender lo barroco desde las perspectivas más diversas. Haciendo referencia tanto a un pasado como al presente desde el que se enuncia, el término queda cargado de una controvertida carga (de presente) con la que irrumpe en medio de la Modernidad culta, ilustrada y racionalista, con la que paradójicamente se le alcanza a identificar (Buci-Glucksmann; Calabrese; Buck-Morss; Lucas; Van Reijen; Rincón; Echeverría; Cornago). La potencia de actualización y crítica del concepto, fácilmente traducible en términos ideológicos, es la que explica su creciente vitalidad desde hace más de un siglo.

Metodológicamente sería necesario, por tanto, comenzar dando la vuelta a la pregunta sobre qué es el barroco para plantearse por qué en un momento dado se tiene la necesidad de recurrir a dicho concepto, y dando un paso más, por qué a partir de ese punto el debate sobre lo barroco no ha dejado de atravesar discursos tan diversos de la Modernidad, o en otras palabras, por qué tantas voces originarias de la Modernidad, ya sea desde el pensamiento crítico o la creación artística, han recurrido a este concepto.

Un imaginario barroco, que no ha dejado de transformarse desde el romanticismo gótico y el simbolismo tardío hasta la era de los medios y la realidad virtual, sobrevuela el horizonte cultural y artístico de la Modernidad. Ésa es la tesis que señala la necesidad de preguntarnos por la extraña relación de amor y odio entre nuestra contemporaneidad racionalista y las connotaciones de exceso y espiritualidad barrocas; no ya el determinar 
si el siglo XX es un siglo barroco por antonomasia, o si se trata de una apropiación indebida o un movimiento cíclico que retorna una vez más en el novecientos, sino de algo previo a todo esencialismo identitario; se trata, como corresponde además a la idea del barroco, de arrojar un enfoque teatral que haga visible la puesta en escena del mismo discurso sobre lo barroco: ¿desde qué escenarios de la Modernidad se ha reformulado una y otra vez la idea del barroco?

Dicha mirada escénica va a terminar iluminando otros montajes de la Modernidad de apariencia más clásica, denunciando su pretendida transparencia, necesidad y buen gusto. Todo ello transforma la pregunta inicial sobre el barroco en otra de orden más amplio: ¿qué modernidades para qué barroco y qué barroco para qué modernidades?, ¿cómo pensar el barroco en el siglo XX?, y viceversa: ¿cómo pensar el siglo XX desde el barroco?, ¿qué nos dice la idea del barroco sobre una época que no ha querido abandonar ya esa perspectiva de análisis, ese modo (barroco) de entender la realidad y la historia, en última instancia, de situar al sujeto frente al mundo?

\section{LA MODERNIDAD COMO REPRESENTACIÓN DE SÍ MISMA}

Iniciemos la andadura con una mirada desde afuera, desde la butaca de platea, como meros espectadores de estos escenarios barrocos que proliferan en la era de los medios. En tanto que mirada característica de la Modernidad, el barroco se traduce no en una, sino en una multitud de representaciones que se han ido construyendo a medida que avanza la contemporaneidad; son historias que, desde el propio Hegel hasta voces más inmediatas, sólo aparentemente más (pos)modernas, como George Steiner, nos hablan de un final, de una historia de decadencia con la que se cerraría la aventura ilustrada de la humanidad, la emancipación del hombre en función del saber, de la ilustración y las letras, del Humanismo. La historia (barroca) de la Modernidad es siempre la última historia, un final tantas veces reformulado, con el que se trata en vano de cerrar la Historia sobre sí misma. Un Ulises confuso embarcado en un viaje de regreso que no tiene fin, pero que siempre está acabando, desde que empezó, repitiéndose a sí mismo, el mismo pero diferente. La Modernidad es una historia (mítica) de la que ya se conoce el final (catastrófico), porque no deja de suceder. Como advirtieron Horkheimer y Adorno ya en 1944, la Ilustración se recubre con las vestiduras del mito, de lo natural que termina denunciando lo que de sobrenatural no ha dejado de haber en todo ello, aquello que se creyó haber expulsado en beneficio del racionalismo secularizador, lo inhumano, quizá por ello también monstruoso, hacia lo que la Modernidad muestra tanta repulsión como atracción.

La frase «El dominio del hombre sobre la naturaleza lleva consigo, paradójicamente, el dominio de la naturaleza sobre los hombres» (Dialéctica de la ilustración, 30) podría erigirse en lema funesto grabado al pie de una de esas escenas apocalípticas de cuerpos masacrados, deformes, que abren la película de Godard o en la cabecera de esos paisajes — después de la batalla - de Juan Goytisolo, historias antiguas que sólo los medios de comunicación modernos han hecho posibles en su actual formulación, trayendo lo más lejano hasta el corazón de los hogares, lo más extraño confundido con lo más cotidiano, lo real transformado en un juego de luces sobre una pantalla, la muerte como lo otro 
(mediático) del sujeto, que lo mira todo desde su lado, del lado de una realidad débil, contaminada, inestable, a pesar de sus apariencias (escénicas) de seguridad.

Como todo mito, la Modernidad se repite una y otra vez, poniéndose en escena, y lo que se repite es el mito de la Modernidad, el mito de lo nuevo una vez más, sucediendo cada vez con mayor eficacia (escénica). Cada historia es siempre la última, una nueva última historia que comienza con la propia Modernidad, desglosada en romanticismos y crisis finiseculares, en vanguardias y posmodernidades, capítulos siempre finales de un relato cuyos orígenes se han querido encontrar en un tiempo tan remoto como la Grecia clásica, tan alejado como esos campos de exterminio que aparecen por televisión. Lyotard afirma que el relato de la decadencia no le sobreviene a la Modernidad en su etapa final, tantas veces repetida, sino que nace con sus orígenes, poniendo en escena una vez más el mito (de lo nuevo): «Estamos tentados a creer, pues, que hay un gran relato de la declinación de los grandes relatos. Pero, como sabemos, el gran relato de la decadencia ya tuvo lugar en los inicios del pensamiento occidental, en Hesíodo y en Platón. En realidad, el relato de la decadencia acompaña al relato de la emancipación como su sombra» ( $L a$ Posmodernidad, 40).

El relato barroco de la Modernidad queda contenido en un escenario, en una imagen (virtual) donde se representan más catástrofes, escenarios ruinosos que cuentan historias de exterminio, escenas apocalípticas que atraviesan la escritura de Goytisolo, historias también de traiciones, como la que da pie a la Reivindicación del conde don Julián. La Historia traicionándose a sí misma, la filosofía - como nos recuerda Adorno al comienzo de la Estética negativa- faltando a su promesa de ser igual o estar en vísperas de producir la realidad, obliga al pensador tanto como al poeta a abrazar él también el estandarte de la disidencia, de la traición, la violencia como forma (barroca) de pensamiento, de creación. La escritura convertida en acto, y el acto hecho poesía, la poesía transformada en acción y la acción en performance, la música puesta en pie a través de las imágenes -Nuestra música - y las imágenes sublevándose contra la Historia: «la violencia, la violencia siempre: jalonando discretamente tu camino: convincente y súbita: anulando de golpe el orden fingido, revelando la verdad bajo la máscara, catalizando tus fuerzas dispersas y los donjulianescos proyectos de invasión: traición grandiosa, ruina de siglos: ejército cruel de Tariq, destrucción de la España sagrada» (Goytisolo, Reivindicación, 52)

Bajo ese imaginario de destrucción, de impureza, pero también de juego y gozo, se construyen mundos tan distintos como la poesía cinematográfica de Godard, la escritura de Goytisolo o el cine de Peter Greenaway, escenarios cambiantes que hacen visible el texto o las imágenes como procesos de construcción y destrucción al mismo tiempo, como estrategias (barrocas) de resistencia frente a formas de poder impuestas (Cornago, Resistir): "Víctimas de la brutalidad de la Historia, nos vengábamos de ella con nuestras historias, tejidas de ocultaciones, textos interpolados, lances fingidos: tal es el poder mirífico de la literatura", dice una de las voces, alter ego del propio autor, en El sitio de los sitios (155).

Greenaway insiste en que el cine es el arte barroco por excelencia, el medio de las ilusiones y los engaños ópticos, un mecanismo que se erige en metáfora, también epistemológica, de una época que él mismo define como barroca: «La fin de notre siècle me paraît baroque de deux points de vue: d'abord l'excès de détails, la masse de informations, et ensuite l'idée de l'illusion et son corollaire, la tromperie avec son cortège de propagandes, 
qu'elles soient politiques ou publicitaires» (cit. en Cieutat y Flechniakoska, 8). Cada imagen denuncia su naturaleza fílmica, construida, al igual que cada representación social, política o moral se manifiesta en su mismo gesto teatral como un juego de intereses, de poder. En 1993 el director galés recrea en The baby of Mâcon el universo exuberante del dramaturgo y escenógrafo Ben Jonson. La película se deleita mostrando en exceso el detallado proceso de representación (construcción) de un misterio medieval en un tiempo apocalíptico arruinado por los intereses políticos, la mezquindad y la lujuria; todo ello inevitablemente vinculado a una minuciosa puesta en escena del poder y del placer, estrechamente ligados, como también vio Barthes en las construcciones de Sade, Fourier y Loyola, representaciones ritualizadas de una transgresión convertida en utopías del cuerpo, de la organización social y la comunicación espiritual. En el escenario (erótico) de los cuerpos la Modernidad confiesa su mórbida atracción por lo excesivo, por lo deforme.

El barroco es también la afirmación de esas representaciones, aunque sea sobre sus propias ruinas, sobre sus propias deformidades. Pero es un relato que nace, en todo caso, con una profunda vocación temporal, con una fuerte conciencia del paso del tiempo y de los estragos que - sobre la Historia (de los cuerpos) - éste va dejando, y por ello con un incondicional sentido de presente desde el que se construye - $-\mathrm{y}$ construyéndolo se goza- dicho relato de acabamiento y excesos. De ahí su profunda conciencia escénica, de estar-representándose, por lo que antes que de un relato podemos hablar de un teatro (barroco) de la Modernidad. Ese escenario se alza sobre una arraigada conciencia de sus limitaciones temporales, espaciales, pero sobre todo epistemológicas, lo que le confiere un profundo sentido trágico, pero también una decidida voluntad de mirar más allá, de seguir siendo, aunque sea a través de esos retazos, sobre sus propios cuerpos (fragmentados); una voluntad de volver a ser, una vez más, en cada representación. Ello explica esa mirada melancólica a la que se refiere Benjamin, tan llena de tiempos, de memoria y pasados, y por ello también de destrucción, pero igualmente movida por una fuerza irracional de vida, de seguir mirando, actuando en el escenario presente (de la historia), de seguir-siendo.

El relato barroco de la Modernidad se escenifica desde el gesto de un rostro vuelto hacia atrás, como el de aquel Angelus Novus, de Paul Klee, convertido en alegoría de la historia en la IX Tesis de Benjamin; una mirada que observa con pavor las catástrofes que se van acumulando al hilo de lo que se llama progreso — textualmente For-schritt, paso adelante-, pero que no deja por ello, desde ese ir hacia delante mirando el pasado, de sentir su presente, efímero e inconcluso, físico y vivo; sino al contrario, esa mirada que Benjamin define como dialéctica se vincula más intensamente —más trágicamente- a ese aquí y ahora desde el que se proyecta, desde el que se construye, por ello es revolucionaria, aunque sea desde ese paisaje de destrucción que deja el paso del tiempo, pero concreto en su cualidad física y material, es decir, escénica.

Esta historia implica, por tanto, una vocación arqueológica, desde la que nace la Modernidad, desde Nietzsche a Foucault, como un ejercicio de búsqueda y re-visión, de volver a ver una vez más, siempre una vez más, como quería el filósofo de Basilea, existiendo únicamente en ese eterno retorno, siempre diferente y singular, de un presente (de representación) que se consume en cada momento de iluminación; una iluminación que alumbra la noche de la razón capitalista, la pesadilla más negra de la Modernidad, pero también el placer de seguir siendo (representación) físicos e inmediatos, concretos y 
singulares en medio de esa travesía por la helada inmensidad de la abstracción de la que hablara Benjamin.

El teatro barroco de la Modernidad está construido sobre citas y fragmentos, en modo imperfecto, pero a diferencia de otro tipo de representaciones éstas exhiben con impúdica desesperanza, desde un estado de trágica conciencia, los jirones sobre los que se construyen, sabiendo que cada una de esas voces contiene en sí misma una historia más de esa Modernidad oscura y brillante, yuxtaposición inconexa de todos los paraísos e infiernos que se han sucedido, promesas y debacles atrapadas en cada una de esas alegorías (de la Modernidad) del tiempo presente. Es una historia de resignación y sumisiones, pero también de protesta y resistencia, como las vidas de esos santos de la disciplina y el placer puestas en escena por Goytisolo en la Carajicomedia, luchando (y gozando) a lo largo de los siglos en un intento por seguir-resistiendo (siendo), en un continuo devenir, estado de variaciones y metamorfosis, porque como dice ese otro autor de abigarrados escenarios poblados por grotescas figuras en constante peligro de disolución que fue Elias Canetti, "sólo a través de la metamorfosis, entendida en el sentido extremo en que empleamos aquí el término, sería posible percibir lo que un ser humano es detrás de sus palabras; de ninguna otra manera podría captarse lo que de reserva vital hay en él» (358).

\section{ESCENIFICACIONES DEL TIEMPO: UN JUEGO CON LOS LÍMITES}

Sin embargo, ese presente incierto del yo pensándose a sí mismo inaugura un tiempo del después de, en el que se instala la Modernidad, creciendo desde un profundo sentimiento de finitud, de estar al final de algo, o ya más bien en el después de ese final inminente, que pasa a ser inmanente, como señala Kermode. Igual que en el Teatro de la Muerte de Kantor, la representación empieza cuando ya todo ha terminado; el telón se levanta en ese después de la historia y las revoluciones; todo pasó ya antes. El sujeto asiste perplejo a un juego cuyas reglas se imponen de manera fatal. Tras la crisis de los Estados-nación a la que se refieren Hardt y Negri en Imperio, las reglas ya no dependen de la economía nacional de cada Estado, sino que se construyen sobre un tablero global ampliado al resto del mundo, un capitalismo más consciente de sí mismo, como toda la Modernidad, menos pudoroso. A ese escenario vacío del después de, donde se agolpan los recuerdos desordenados de un pasado que ya no es, de una historia de progreso, igualdad y justicia que nunca ha sido, salen una vez más los personajes de Kantor, que son los personajes del siglo XX, soldados atados a sus fusiles y generales sobre sus caballos, curas y rabinos mostrando sus cruces, siniestros familiares que salen de algún oscuro pasado, ingenuamente liberados del sentimiento de culpa, convertidos en máscaras de sí mismos, para tratar de revivir su niñez, sus historias de decadencia y destrucción, de una Polonia habitada por los muertos que dejaron los uniformes; repiten una y otra vez los mismos gestos, las mismas acciones, que se hacen cada vez más estúpidas, más inútiles, como los objetos que arrastran consigo, restos del naufragio que llegan hasta las playas de una Modernidad escindida en la representación imposible de lo nuevo, que es lo mismo, la misma historia animada por un mito que trata de cerrarse sobre sí mismo, sobre su destino como cumplimiento de una razón universal. Cerrar el viaje, como Ulises, para regresar al punto de partida, y constituirse en una sola Historia con un solo sentido, completa y autosufi- 
ciente, igual a sí misma; pero Ítaca se ha convertido en una agencia funeraria donde se apilan muebles viejos, una agencia de colocación de actores de aspecto sospechoso que simulan ser quienes no son, una cantina de una estación de tren donde ya sólo llegan los extraviados.

En este tiempo (de la representación) todo pierde el sentido lógico de esa historia previa que nunca fue; todo se revela pura actuación, juego de sustituciones y apariencias, sujeto a una nueva lógica, que es la lógica escénica de esa Historia, la historia del capital emancipado sobre sí mismo, de los signos hechos visibles funcionando de manera autónoma; acciones, textos, cuerpos y sonidos chocando unos con otros. Los actores quedan convertidos en personajes de una obra que no comprenden, porque el relato único (de la Modernidad) se ha averiado y sólo resta la posibilidad de seguir actuando, para que la maquinaria (de la representación) siga en pie, desde el plano de inmanencia formado por los propios cuerpos-actores en acción, por la materialidad de los objetos inservibles, por la energía colectiva producida por todo el conjunto, que por momentos resurge del desorden para revelarse en un único canto rítmico como una fuerza colectiva (deseante), la fuerza emergente de las multitudes, a las que se refieren Hardt y Negri (Multitud) como la posibilidad para una democracia en la sociedad global. Esa democracia no pasa ya por el pueblo, el proletariado o la masa, por el teatro dramático del capitalismo industrial, sino por las multitudes, irreducibles a la unidad, informes, próximas también a lo monstruoso, el caos (vitalista) de lo que todavía no ha sido ordenado, compuesta de singularidades, diferencias emancipadas - como el capital - transformadas en motores de resistencia contra los destinos organizados por las Historias; poblaciones sublevadas contra las reglas del juego, movimientos desesperados de individuos, como los que se agolpan en el imaginario barroco de Goytisolo, confundiendo siglos de historias. Ésa es la posibilidad de seguir pensando la Historia como resultado de un deseo creador. «El impulso de destrucción de las masas era al fin de cuentas su instinto creador más profundo?» (La saga de los Marx, 52) se pregunta un confundido Doctor Marx en medio de una exultante sociedad de consumo que hace tiempo que dejó de pensar en revoluciones para centrarse en producir y consumir, lo que sea, pero con exceso.

La saga de los Marx se abre con las imágenes (televisivas) de una soleada playa privada en la costa italiana amenazada por el inesperado desembarco de un ferry atestado de fugitivos albaneses, imágenes que el «zapeo convulsivo de Tussy» (la hija menor de Moro) hacía contraponer con el «sofisticado transatlántico reconstruido en los estudios de Cinecittà» (20). La misma maquinaria de la representación que parece imponer un orden se resiste monstruosa a una economía de la identificación, de la reducción de lo otro a lo mismo; es el teatro barroco (de la Modernidad) donde todo es lo que parece, acartonado, falso, pero al mismo tiempo también otra cosa, extraña, desconocida, física y desmesurada, como ese «herrumbroso y maltrecho transbordador de jubilosa y exultante carne humana» (20) que mira al espectador retándole a descubrir, como las alegorías de Benjamin, el sentido oculto de lo que está viendo desde el otro lado (de la pantalla), desde ese aparente después de que inaugura la escenificación de la Modernidad. 


\section{ESCENIFICACIONES DEL ESPACIO: EL EXCESO OPACO DE LAS PRESENCIAS}

Desde ese aparente no-tiempo, por el que transitan los héroes de Joyce perdidos en el aquí y ahora de las palabras o los personajes de Beckett en el presente suspendido del escenario - agujero negro que absorbe todos los sentidos y todas las historias-, se manifiesta con enigmática claridad el propio espacio (de representación) de una desaparición. Frente a la disolución de la conciencia temporal, difuminada en mil tiempos paralelos, se ilumina un acto de disolución, un espacio para el acontecimiento, invitación al juego de las sustituciones sin fin, de las ausencias y las presencias, del soy yo pero represento a otro, del descubrimiento de lo otro dentro de lo mismo. En los albores del siglo XX, dando fe de otra historia de decadencia, la del Imperio Austrohúngaro, la de una Europa que acabaría con la Guerra Mundial, Hugo von Hofmannsthal nos hace ver el espacio de esa disolución provocada por la proliferación excesiva de conceptos y abstracciones: «Todo se descomponía en partes, y cada parte en otras partes, y nada se dejaba ya abarcar con un concepto. Las palabras, una a una, flotaban hacia mí; corrían como ojos, fijos en mí, que yo, a mi vez, debía mirar con atención: eran remolinos, que dan vértigo al mirar, giran irresistiblemente, van a parar al vacío» (31).

Un tiempo vivido como crisis de todo lo estable obliga a continuos «actos de invención» — como dice Eco (78), calificando la espiritualidad barroca como la "primera clara manifestación de la cultura y de la sensibilidad modernas»-. Esa capacidad creativa, metamórfica, permite seguir pensando una realidad en constante movimiento, cuyos signos vuelven a revestirse de la condición enigmática que ya ostentaron en épocas sólo aparentemente menos claras. Ese espacio (de invención) es también, una vez más, una invitación a la resistencia a partir de la revelación de una materialidad concreta, del mundo como (voluntad de) representación y por ello de juego y gozo, de placer (físico) y pensamiento, una resistencia que adquiere los rasgos de una acción en proceso, aquí y ahora, performativa. Esa tarea infinita de interpretación, y a la vez de invención, constituye al hombre moderno, enfrentado a una «gigantesca maquinación para dotar de sentido expreso el mundo» que es el Barroco — según lo define Fernando de la Flor (11)—, pero también la Modernidad (barroca). Es el «hombre estructuralista» de Barthes, revestido de esa condición operacional con la que Deleuze califica el barroco de Leibniz, que busca los sentidos en los procesos (de construcción) antes que en los resultados, en los modus operandi antes que en los productos, en los escenarios antes que en las historias, en los ritmos de esas maquinarias; así, el hombre estructuralista "prête l'oreille au naturel de la culture, et perçoit sans cesse en elle, moins des sens stables, finis, ‘vrais`, que le frisson d'une machine immense qui est l'humanité en train de procéder inlassablement à une création du sens, sans laquelle elle ne serait plus humaine. Et c'est parce que cette fabrication du sens est à ses yeux plus essentielle que les sens eux-mêmes» (Barthes, Essais, 227).

En ese espacio iluminado ya no hay lugar para la transparencia, para la adecuada identificación de significantes y significados, de lo otro con lo mismo; todo se alza bajo el signo de la no coincidencia, y por tanto del exceso, que hace visible los límites en el momento de su transgresión. La mirada barroca descubre un mapa de confrontaciones alzado sobre un espacio convertido en el escenario de una actuación; los discursos y relatos que abarrotan los escenarios de la Modernidad se descubren como otros tantos actos (de representación). La mirada barroca saca a la luz todas las representaciones, 
convierte en juego y simulacro lo que observa, sub species theatralis, como el ojo de la cámara de Greenaway, desvelando cada imagen como una medida puesta en escena, cada trama como una ceremonia de perversión, cada ficción como un contrato fatal que vincula, en primer lugar, al propio espectador que acepta entrar en el juego. El que mira, transformado en actor protagonista de la representación, en voyeur del escenario íntimo de una violación (monstruosa), se hace también visible dentro de este teatro que, movido por una vocación de exceso (de deformidad), tiende a mostrar siempre demasiado, hasta llegar — como explica Baudrillard - a la obscenidad de la representación capitalista, donde todo se finge transparente, se actúa como si fuera realidad, como en el escaparate televisivo, sin escena, sin teatro y sin ilusión, "sometido a la cruda e inexorable luz de la información y la comunicación» (18).

Pero como víctima propiciatoria de ese escenario sacrificial aparece el signo (de ese exceso), el cuerpo en primer lugar de la propia escritura, de la palabra inscrita en el vacío de la página en blanco; puesta en escena que, como soñó Mallarmé, sólo producirá el espacio como acontecimiento de un azar, pues «nada [...] habrá tenido lugar [...] sino el lugar» (132-133). Y a la revelación de la materialidad física de la escritura, del cuerpo del lenguaje, vendrá unido el gozo de una transgresión, una acción cuyo sentido es el placer de lo que acaba en el mismo instante en que nace, irreductible, como la propia representación. El barroco surge en el horizonte de la Modernidad como una reivindicación de la cualidad erótica del lenguaje. En palabras de Barthes: «seul le baroque, expérience littéraire qui n'a jamais été que tolérée par nos sociétés, du moins la française, a osé quelque exploration de ce que l'on pourrait appeler l'Éros du langage» (Le bruissement de la langue, 18); un gesto que se resiste a ponerse en función de todo lo que no sea él mismo, ocurriendo de nuevo con cada representación, sucediendo excesivo una y otra vez en ese espacio hecho visible, paralizando, como en una foto fija, la pretendida naturalidad de cualquier discurso que busque su rentabilización al servicio de alguna «buena causa»; es el placer de la escritura como política de la representación de los propios cuerpos, empezando por el cuerpo-acción de la escritura levantada sobre la escena (física) de la página en blanco. El exceso opaco de esa presencia-acción puesta en escena sabe ya que la dimensión social de un texto, como de una imagen:

ne se mesure ni à la popularité de son audience ni à la fidélité du reflet économico-sociale qui s'y inscrit ou qu'il projette vers quelques sociologues avides de l'y recueillir, mais plutôt à la violence qui lui permette d'excéder les lois qu'une société, une idéologie, une philosophie se donnent pour s'accorder à elles-mêmes dans un beau mouvement d'intelligible historique. Cet excès a nom: écriture (Barthes, Sade, Fourier, Loyola, 14).

La búsqueda de esa cualidad concreta y material se revela también como una pieza clave en el pensamiento de Benjamin para llegar a la imagen dialéctica, así como de la posterior teoría crítica de la Escuela de Frankfurt; de ahí la evolución de Adorno hacia la estética, hacia lo concreto de la percepción como un modo de corregir el mecanismo de poder que acompaña a la dialéctica racionalista de la Ilustración, al mecanismo perverso que encadena un concepto a otro, denunciado incansablemente por otro de los espíritus barrocos por excelencia de la Modernidad, Miguel Romero Esteo.

La escena (teatral) del siglo XX se hace visible sobre su propia materialidad, sobre la presencia de los cuerpos, de las palabras y del mismo pensamiento convertido en acción. En ese contexto, Romero Esteo insiste en diferenciar racionalismo y racionalidad: "la 
racionalidad funciona en la concreción y la materialidad de las cosas, y por eso diferencia y diversifica. El racionalismo funciona en la abstracción, y por eso uniformiza cretinamente a las cosas multiformes» ("A modo», 32); la primera conduce a una libertad de expresión, mientras que la segunda funciona como represión de la realidad en función de las abstracciones.

Esa mirada material y barroca, erótica, desnuda las representaciones de su aparente inocencia, desvelando todo acto de puesta en escena como un ejercicio de seducción del otro, y por tanto de poder; pero por ello también de placer cuando ese sometimiento se realiza de manera voluntaria. Perdida la supuesta inocencia de las representaciones, de los discursos y los conceptos, el tiempo presente, cercano y familiar, se hace extraño y enigmático, como en una alegoría, que Benjamin transforma para la Modernidad en imagen dialéctica. Unas y otras se construyen desde esa explícita voluntad escénica; nacidas para mostrarse, como la propia Modernidad, ordenan mediante un ejercicio de ostentación los retazos enigmáticos que la componen, dando lugar a un campo de fuerzas, de tensiones y enfrentamientos, como los escenarios de Kantor, donde cuerpos, palabras, lógicas y ritmos se alzan contra cualquier idea de totalidad, de unidad de sentido.

Un exceso de ordenación regula la disposición (escénica) de lo que está pensado para ser mirado, para ser consumido. Tras esa proliferación de objetos que abarrotan los escaparates de la Modernidad se esconde un límite y un deseo, detrás de los cuales se abre un espacio informe que niega el sentido aparente de lo que se deja ver; lo familiar y cercano se convierte en signo de una verdad oculta que no se alcanza a descifrar. La curiosa clase media se agolpa ante los escaparates de un nuevo negocio que acaba de abrir sus puertas en la ciudad. Es una fotografía en blanco y negro con los bordes amarillentos; puede ser un documento sociológico del siglo XIX o una alegoría que transforma los cuerpos deseantes en calaveras ante un escaparate vacío que sólo contiene los rostros huecos reflejados en un pequeño espejo, único objeto que queda en las vitrinas del comercio. El lema de esta alegoría lo tomamos de una cita de Paul Morand («L'avarice», 26-27) recogida por Benjamin $(\mathrm{H} 2 \mathrm{a}, 3)$ : «La necesidad de acumular es uno de los signos precursores de la muerte tanto en los individuos como en la sociedad». La mirada dialéctica descubre la realidad como un espacio de contrastes llevados al extremo, paraísos e infiernos dispuestos, como en los barrios marginales de las grandes urbes, en vergonzante promiscuidad, más allá, como la lógica del capital, de su sentido aparente.

\section{LOS TEATROS DE LA VERDAD: REPRESENTACIONES EPISTEMOLÓGICAS}

A comienzos de los ochenta Foucault responde al planteamiento sobre ¿qué es la Ilustración? comentando el texto de Kant que dos siglos antes llevaba ya por título dicha pregunta. A juicio de Foucault, Kant destaca antes el contenido de la Revolución Francesa, a la que nace ligada la Ilustración, que los signos marginales, como la mirada desde la que se construye ese evento, «el modo mediante el cual la Revolución se hace espectáculo» $\mathrm{o}$ «la manera en que es acogida en la periferia por los espectadores que no participan en ella pero que la contemplan y asisten a ella» (203). La Ilustración nace como un giro autoconsciente, como una mirada explícita sobre sí misma; los espectadores que asisten a los actos revolucionarios inauguran una manera originaria de mirar el teatro de la historia. 
Esa actitud, que define la episteme moderna, es decir, el modo en el que el saber moderno se constituye, es definida por Foucault como una ontología crítica del presente. Coincidiendo con la definición del estructuralismo que el propio autor ofrece, se trataría de «la conciencia despierta e inquieta del saber moderno" (Las palabras y las cosas, 206). El escenario del saber ya no apunta a una metafísica trascendental, tampoco a una escuela o un método, sino a un campo de inmanencia desde el cual el mismo sujeto que mira, que se cuestiona, se constituye como tal, resultado de las condiciones económicas, sociales y sicológicas que definen su presente. La Modernidad, como la Ilustración de la que participa, adquiere su actualidad en ese giro autorreflexivo - operación estructuralista- que la hace ser consciente de sí misma, construir de manera consciente su propia puesta en escena, «tanto en relación a la historia general del pensamiento, como en relación a su presente y a las formas de conocimiento, de saber, de ignorancia y de ilusión en las que sabe reconocer su situación histórica» (Foucault, ¿Qué es la Ilustración?, 200).

Una ontología crítica del presente es una ontología del propio sujeto construido de manera consciente sobre los límites de la razón, pero no para aceptar ya sus fronteras, como tácitamente se desprende de la crítica kantiana, sino para preguntarse por la posibilidad de su franqueamiento, lo que implica a su vez la pregunta por lo que uno es, ahondar en «la contingencia que nos hizo ser lo que somos la posibilidad de ya no ser, hacer o pensar lo que somos, hacemos o pensamos» (105).

La teatralidad originaria de la Modernidad consiste en una puesta en acto de la historia, del saber y las identidades, de modo que sobre ese escenario se levante un signo de interrogación. Dicha función crítica caracteriza el modo de representación dialéctico, barroco y materialista en la época contemporánea, construyéndose, como explica Bernard Dort en La representación emancipada, sobre unos elementos, cuerpos e imágenes, textos y acciones, que ya no se dejan ordenar en función de un sentido impuesto desde afuera: "Aujourd'hui, par l'émancipation progressive de ses différentes composantes, elle [la théatralité] s'ouvre sur une activation du spectateur et renoue ainsi avec ce qui est peut-être la vocation même du théâtre: non de figurer un texte ou d'organiser un spectacle, mais d'être une critique en acte de la signification» (184).

Antecedente de esa ontología crítica, y escénica, del presente, la figura de Nietzsche ha pasado a la historia posterior de una cultura que se resiste a verse reducida a un cúmulo de representaciones como el gran fustigador de los teatros y las ilusiones. Sin embargo, desde el comienzo de su trayectoria intelectual, puesta en escena con un estudio precisamente sobre los orígenes de la tragedia, el joven catedrático de Basilea insiste en la necesidad de las representaciones, de las ilusiones y de los engaños, porque «toda vida se basa en la apariencia, en el arte, en el engaño, en la óptica, en la necesidad de lo perspectivístico y del error» (La gaya ciencia, 32), y por ello también del arte, el campo por excelencia de las representaciones, de la mentira y lo ilusorio, y entre todas las artes destaca el teatro, un teatro físico y musical, espacio de transformaciones, de placer, dolor y conocimiento, que haga soportable lo que de otro modo sería insoportable, el magma oscuro, dionisiaco, el Uno primordial del que nacen todas las representaciones, no para representar lo irrepresentable, sino para dar fe de que hay algo que escapa a todos los escenarios, sobre lo que se debe levantar también el impulso ético, como décadas después defenderá Lévinas con su formulación del ser-para-el-Otro. Sobre esta verdad (escénica) el hombre levanta un mundo a su medida, que no es la medida de la realidad, sino un mundo traducido a lo consciente, los teatros de la verdad, de la justicia, la moral y 
el derecho, metáforas antropomórficas que con pretensión universalista niegan todo lo que no pueden aceptar, su condición de representaciones de un mundo que escapa a sus limitaciones.

En un gesto que tiene tanto de ético como de estético, polos fundadores y ya inextricables de la Modernidad, el autor de Así habló Zaratustra salta a la escena del pensamiento occidental poniéndose él mismo en escena, haciéndose visible como cuerpo (escritura)pensante, pero por ello, en tanto que se trata de un teatro de las ideas, también como máscara (parlante), de filólogo, héroe trágico o sátiro, en una palabra, como escritura y retórica, cuerpo físico, intensidades orales que definen un estilo híbrido de filosofar, un teatro enérgico del pensamiento que terminará muriendo dentro de la misma escena, recuperado por el relato de la Modernidad como acto sacrificial del pensamiento a su propia condición escénica. Nietzsche se presenta a sí mismo frente a los tribunales de la Modernidad con una profunda conciencia (trágica) de su ser como actuación, una performance marcada por el exceso vital de lo físico, por el «materialismo dionisiano» que Sloterdijk formula en El pensador en escena. En el horizonte de la Modernidad surge la necesidad de una nueva ética (física) del pensamiento, más consciente de que detrás de cada palabra hay un cuerpo, de que antes del logos está el habla, el decir como acción; una ética que «sabe que no existe nada más indecente que la falta de energía que se presenta como ciencia; siente que no existe nada más sospechoso que el miedo a la verdad que se hace pasar por conciencia crítica; y nada más falso que esa incapacidad de reconocimiento que se hace pasar por una facultad superior» (Sloterdijk, 135).

La realidad del pensamiento se revela como un acto escénico, juego de ilusiones, sustituciones y engaños, pero también, como toda representación, afirmación de sí misma, física, inmediata y vital, impulsada, como los personajes de Greenaway, por una pasión por las representaciones y los juegos, pasión por el poder, pero también, en un sentido positivo, por el poder como fuente vital que anima al hombre en su ser-actor, es decir, en su ser-para-el-Otro, en su volver una y otra vez a representarse, en cada instante una vez más; ésos son los teatros de la verdad, la verdad ética y estética, física y política del teatro (de la Modernidad).

Es en ese sentido que el mundo de Kantor, donde los actores se convierten en personajes de sí mismos haciendo ostentación de su perversa misión sustitutiva, hace visible a su propio creador, el director polaco puesto en escena, camisa blanca, bufanda negra, el cigarrillo encendido y el rostro hundido, mientras observa sus figuras, personajes de un pasado que como viajeros del tiempo llegan a este presente de la escena, construido para la mirada de un tercero, del espectador, en el que se transforma inevitablemente el hombre moderno. En ese escenario de las ideas y la vida, de la memoria, todo adquiere su única verdad en la medida en que es visto por el otro, quien con su mirada termina de poner en pie esa representación (de la verdad). Como una alegoría del pensamiento, Kantor observa entre indiferente y perplejo o emocionado, los fantasmas que han venido a visitarle, interrogándolos como quien trata de desvelar el secreto del enigma (de la Historia). La diferencia - escénica-con otras épocas es que dicho personaje, como Nietzsche, se sabe a su vez mirado por otros, de ahí el imperativo escénico - ético- de la Modernidad, fingo ergo sum, o parafraseando a Sloterdijk: «Pensar sobre el escenario genera más verdad» (49). La irrupción física del pensador en la escena, del pensamiento como acción, apunta a una ética somática, hecha posible por el descubrimiento de las psicologías profundas, que están en la base de la Modernidad. 
Frente a la mirada de Kantor se abre un paisaje detenido habitado por actores muertos, muñecos que se aferran a sus cuerpos, una escena que gira en torno al presente de la representación, realizado una y otra vez con cada nueva entrada, siempre de los mismos personajes. Como en una alegoría benjaminiana, la Historia se manifiesta como construcción, como acto explícito de representación puesto en escena. Es un mundo cerrado donde todo denuncia su carácter sustitutorio de otra realidad; todo es falso. La historia moderna como mito de progreso queda transformada en un paisaje detenido que expresa la fugacidad del tiempo. La alegoría llega a captar, en palabras de Adorno, "el Ser histórico como Ser natural en su determinación histórica extrema, en donde es máximamente histórico" (Actualidad de la filosofía, 117). La Historia, como escenificación fundamental del discurso de la Modernidad, manifiesta su naturaleza esencialmente temporal, dejando al descubierto el mito de lo nuevo, que se alza como una interrogación (de un sentido) frente a quien lo mira.

Tratar de escapar a ese escenario buscando un espacio de verdad, un espacio de no representación, supone renunciar a las apariencias para afirmar lo que no se ve, ideales racionalistas en nombre de las cuales se termina llegando a cualquier irracionalismo, como afirma Romero Esteo, o en la formulación de Lyotard: «Los siglos XIX y XX nos han proporcionado terror hasta el hartazgo. Ya hemos pagado suficientemente la nostalgia del todo y de lo uno, de la reconciliación del concepto y de lo sensible, de la experiencia transparente y comunicable» (La Posmodernidad, 26).

La última escenificación de la Modernidad es la de sí misma pensándose una y otra vez material, inmediata y fugaz, al tiempo que se construye como discurso epistemológico, es decir, como condición (puesta en escena) del saber (de la Historia), construcción de los discursos que delimitan las áreas de conocimiento; y con ello del propio pensador, hecho visible, en el acto físico de pensar, instante de la revelación, como quería Benjamin, momento de vida, de verdad en su íntima condición escénica, y por ello excesiva.

La mirada barroca de la Modernidad reivindica y traiciona al mismo tiempo la representación que ella construye, afirmación de un desvío - singular-, de un desplazamiento, de un exceso y una desaparición, visión de paralaje diría Žižek; defiende una realidad física que se afirma antes de cualquier lectura, historia o sentido, inevitablemente escénica, pero no por ello falsa; la única verdad es la verdad de las representaciones tratando de sostenerse por encima del dolor esencial que amenaza al individuo en su sentir trágico, parafraseando la cita de Nietzsche con la que se abre el presente ensayo. Es por tanto una Modernidad proyectada hacia un más allá, es decir, también espiritual, más física cuanto más trascendental en una época paradójicamente posmetafísica, más vital y gozosa cuanto más consciente de su cuerpo (excesivo), para descubrir en el centro de éste, en el centro de las representaciones y los teatros (de la verdad), un punto ciego desde el que volver a proyectarse hacia lo desconocido, desde el que volver a ligarse - religarecon lo trascendental, por ello afirma Lyotard en Dispositivos pulsionales que la escenificación, técnica fundamentalmente política de inclusiones y exclusiones, es también «la religión de la irreligión moderna, lo eclesiástico de la laicidad» (61). Una Modernidad, por tanto, en positivo que en medio del espectáculo mediático (virtual) del capitalismo es capaz de resistir con sus cuerpos, de seguir viendo lo otro, el horizonte infinito - religioso-, que llevó a Nietzsche a decir ya al final de su recorrido intelectual, en La gaya ciencia, que "por fin el horizonte se nos aparece otra vez libre, aunque no esté aclarado, por fin nuestras naves pueden otra vez zarpar, desafiando cualquier peligro, toda aven- 
tura del cognoscente está otra vez permitida, el mar, nuestro mar, está otra vez abierto, tal vez no haya habido jamás mar tan abierta» (254), o en palabras de Romero Esteo, escritas en el ambiente cultural de los años setenta en referencia al libro de Peter Brook, The empty space: "Hay hoy en día una eclosión de ideas nuevas, de novísimas formas de sensibilidad, de insólitas situaciones conflictivas. Vivimos en una sociedad cada vez más multiforme y cambiante. Teatral, en el sentido casi ontológico del término» (27).

\section{REFERENCIAS}

Adorno, Theodor Wiesengrund. Dialéctica negativa. Madrid: Taurus/Cuadernos para el Diálogo, 1966. Medio impreso.

. «Idea de historia natural». Actualidad de la filosofía. Barcelona: Paidós, 1991. 103-134. Medio impreso.

Barthes, Roland. Essais critiques. París: Seuil, 1964. Medio impreso. . Le bruissement de la langue. Essais critiques IV. París: Éditions du Seuil, 1984. Medio impreso. . Sade, Fourier, Loyola. París: Éditions du Seuil, 1971. Medio impreso.

Baudrillard, Jean. El otro por sí mismo. Barcelona: Anagrama, 1988. Medio impreso.

Benjamin, Walter. Libro de los pasajes. Ed. Rolf Tiedemann. Madrid: Akal, 2005. Medio impreso.

Buci-Glucksmann, Christine. La Raison Baroque. De Baudelaire à Benjamin. París: Galilée, 1984. Medio impreso.

Buck-Morss, Susan. Dialéctica de la mirada. Walter Benjamin y el proyecto de los Pasajes. Madrid: Antonio Machado Libros, 1995. Medio impreso.

Calabrese, Omar. La era neobarroca. Madrid: Cátedra, 1994. Medio impreso.

Canetti, Elias. La conciencia de las palabras. México: Fondo de Cultura Económica, 1981. Medio impreso.

Cornago, Óscar. «Nuevos enfoques sobre el Barroco y la (Pos)Modernidad (a propósito de dos estudios de Fernando R. de la Flor)». Dicenda. Cuadernos de Filología Hispánica 22 (2004). 27-51. Medio impreso.

. Resistir en la era de los medios. Estrategias preformativas en literatura, teatro, cine y televisión. Madrid/Frankfurt: Iberoamericana/Vervuert, 2005. Medio impreso.

Cieutat, Michel y Jean-Louis Flechniakoska. Le grand atelier de Peter Greenaway. París/ Strasbourg: Presses du réel/Université des Sciences, 1998. Medio impreso.

D’Ors, Eugenio. Lo barroco. Madrid: Tecnos, 1993. Medio impreso.

De la Flor, Fernando. La península metafísica. Arte, literatura y pensamiento en la España de la Contrarreforma. Madrid: Biblioteca Nueva, 1999. Medio impreso.

Deleuze, Gilles. El pliegue. Leibniz y el barroco. Barcelona: Paidós, 1989. Medio impreso. Dort, Bernard. La représentation émancipée. Arles: Actes Sud, 1988. Medio impreso. Echeverría, Bolívar. La modernidad de lo barroco. México: Era, 1998. Medio impreso. Eco, Umberto. Obra abierta. Barcelona: Planeta-De Agostini, 1992. Medio impreso.

Foucault, Michel. Las palabras y las cosas. Una arqueología de las ciencias humanas. Madrid: Siglo XXI, 1968. Medio impreso. 
¿Qué es la Ilustración? Madrid: Las Ediciones de la Piqueta / Ediciones Endymión, 1983-1984. Medio impreso.

Goytisolo, Juan. Carajicomedia de Fray Bugeo Montesino y otros pájaros de vario plumaje y pluma. Barcelona: Seix Barral, 2000. Medio impreso.

. El sitio de los sitios. Madrid: Alfaguara, 1995. Medio impreso.

. La saga de los Marx. Barcelona: Mondadori, 1993. Medio impreso.

. Paisajes después de la batalla. Madrid: Austral, 1982. Medio impreso.

. Reivindicación del conde don Julián. Barcelona: Seix Barral, 1988. Medio impreso.

Hardt, Michael y Antonio Negri. Imperio. Buenos Aires: Paidós, 2003. Medio impreso. . Multitud. Guerra y democracia en la era del Imperio. Buenos Aires: Debate, 2004.

Medio impreso.

Horkheimer, Max y Theodor W. Adorno. Dialéctica de la Ilustración. Fragmentos filosóficos. Madrid: Trotta, 1994. Medio impreso.

Kermode, Frank. El sentido de un final. Estudios sobre la teoría de la ficción. Barcelona: Gedisa, 2000. Medio impreso.

Lucas, Ana. El trasfondo barroco de lo moderno (Estética y crisis de la Modernidad en la filosofía de Walter Benjamin). Madrid: UNED, 1992. Medio impreso.

Lyotard, Jean-François. Dispositivos pulsionales. Madrid: Fundamentos, 1981. Medio impreso.

. La Posmodernidad (explicada a los niños). Barcelona: Gedisa, 1987. Medio impreso.

Mallarmé, Stéphane. Un golpe de dados. Antología. Madrid: Visor, 1971. Medio impreso.

Nietzsche, Friedrich. El libro del filósofo. Madrid: Taurus, 1974. Medio impreso. . La gaya ciencia. Madrid: Akal, 1988. Medio impreso.

Rincón, Carlos. Mapas y pliegues: ensayos de cartografía cultural y de lectura del Neobarroco. Santafé de Bogotá: Colcultura, 1996. Medio impreso.

Romero Esteo, Miguel. "A modo de introducción que no introduce nada». El vodevil de la pálida, pálida, pálida pálida rosa, Madrid: Fundamentos, 1979. 7- 56. Medio impreso.

. «Peter Brook. The empty space». Nuevo Diario, 9 de mayo de 1971. 26-27. Medio impreso.

Sloterdijk, Peter. El pensador en escena. El materialismo de Nietzsche. Valencia: PreTextos, 2000. Medio impreso.

Van Reijen, Willem. Die authentische Kritik der Moderne. München: Fink, 1994. Medio impreso.

Von Hofmannsthal, Hugo. Carta de Lord Chandos. Madrid: Colegio Oficial de Aparejadores y Arquitectos, 1982. Medio impreso.

Žižek, Slavoj. Visión de paralaje. Buenos Aires: Fondo de Cultura Económica, 2006.

Recepción: 4 de agosto de 2011

Aceptación: 3 de octubre de 2011 